\title{
DIFFERENT STROKES: JUDICIAL VIOLENCE IN VIKING-AGE ENGLAND AND SCANDINAVIA
}

\author{
Keith Ruiter \& Steve Ashby ${ }^{1}$
}

\section{Introduction}

Crime and deviance stand as real challenges in all societies, and examining the ways in which cultures accommodate and react against transgressive individuals can prove instructive (Hall 2012; Baier 2013). As Alison Klevnäs has recently emphasized (2016a, 54), the study of deviance, violence, politics, and power is tightly entwined with death, and these 'necropolitics' have the potential to catalyse scholarly debate. These considerations find special currency in the Viking Age, given its characteristic increase in cultural contact and interaction, changing religious contexts, and socio-legal developments. Relying on an interdisciplinary and comparative approach to evidence for judicially-prescribed violence in the Viking Age, we explore and highlight new macroscopic details of the English and Scandinavian systems of punishment and some of the ideas permeating them. ${ }^{2}$ We argue throughout that key distinctions

\footnotetext{
${ }^{1}$ Keith Ruiter (keith.ruiter@abdn.ac.uk) is a Doctoral Candidate at the University of Aberdeen's Centre for Scandinavian Studies. Steve Ashby (steve.ashby@york.ac.uk) is a Senior Lecturer in Archaeology at the University of York.

Abstract: This paper takes a fresh look at the use of judicial violence in the societies of VikingAge England and Scandinavia. Using interdisciplinary methodologies, it considers legal, historical, literary, and archaeological evidence for judicially-prescribed maiming and execution. Using this evidence, it describes the English and Scandinavian systems of judicial violence in new detail, reflecting on important aspects of each in turn before turning to a more comparative approach to redirect debate and focus future work.
}

Keywords: Violence, medieval law, punishment, landscape, Canute the Great.

${ }^{2}$ Here 'English' refers to the early-medieval, linguistically Germanic population of the island of Britain. 'England,' therefore, is used only to refer to the geographic location of this population. The term 'Anglo-Saxon' is only used occasionally in reference to other scholars' works referring to the broad period of time c. 450-1066 CE. For more information on the period and the population of Britain at this time, see Reynolds (1999, 23; 13-35). Likewise, 'Scandinavian' here refers to the linguistically Germanic early-medieval population of the Scandinavian peninsula, Jutland, and the islands that make up modern Denmark, as well as their diaspora (Richards 2005, 8-18). These terms attempt to move away from issues of ethnicity in these considerations, preferring instead to look at the legal and social structures in the distantly related cultural groups encompassed by these terms. We acknowledge that these were not entirely monolithic, homogenous groups in terms of culture or language, so, due to the emphasis on vernacular texts in this paper, terms broadly encompass the populations of Old English and Old Norse speakers. Notably, evidence from contemporary Iceland has been excluded as, without executive power, judicial violence operated in a rather different fashion (Hastrup 1985, especially chapters 4 and 8). 
are visible between the English and Scandinavian punishment systems and conclude by exploring these systems interacting during Knútr the Great's English reign.

\section{Judicial Violence and Deviance}

Judicial violence can be understood as judicially-prescribed force enacted on an offender as legal punishment in cases of criminal transgression. Extant sources suggest that, at this time, both Scandinavia and England recognized a hierarchy of judicial violence, moving from marking, branding, or maiming in the case of somewhat lesser crimes to blinding, variations of amputation, and execution in more serious cases. ${ }^{3}$ This violence should be understood as a legal punishment, ordered by an official, legally-empowered body and carried out by judicial imperative. Thus, it differs from ordeal in its aim to punish the guilty, not ascertain guilt; from murder in its lawful operation; from human sacrifice in its legal, rather than ritual, concerns; and from injury in battle in its perceived impartiality (Reynolds 2009, 1-33).

Related is the legal practice of outlawry, since here the threat of judicial violence remains as motivation for the outlaw to stay out of contact with the community (Larson 1935, 17). This stands apart from other forms of exile - which can be illegally-, informally-, or self-imposed and in certain cases the guilty party could repurchase their peace and freedom from the legal authorities (Larson 1935, 17). This payment was commonly known as skógarkaup in parts of Scandinavia. ${ }^{4}$ Thus, legal outlawry can be conceptualized as passively judicially-violent.

Both Viking-Age England and Scandinavia make excellent areas for scholarly investigation of social and criminal deviants, in that both cultures appear to have disposed of a proportion of their 'deviant' dead in archaeologically visible ways. ${ }^{5}$ Recent archaeological study of these 'deviant burials ${ }^{6}$ has proven remarkably productive, with scholars including Andrew Reynolds (2009), Jo Buckberry (2010), Dawn Hadley (Buckberry and Hadley 2007), Eva Thäte (2007), and Leszek Gardeła (2013a; 2013b) providing new insights into how social and legal outsiders were treated peri- and post-mortem. Despite these studies of deviant burials and ongoing legal

3 See Reynolds (2009, 23-9) and Peel (2015, 209-10) for some examples of these judicially violent punishments in context.

4 Literally 'forest payment', this was the price paid to return to normative society. It corresponds to an Old Norse term for outlawry, skóggangar, 'forest-going'. For more on the manifold outlawry terms across Scandinavia, see Riisøy (2014).

5 See Reynolds (2009, 23-33) for a discussion relating to England and Gardeła (2013a 99-100; Gardeła 2013b, 88-9) and Thäte (2007, 266-73) for Scandinavia.

6 We use the term 'deviant' burial throughout, but exercise care in its usage. Note that a grave exhibiting non-normative features does not inherently imply the presence of a social or criminal deviant (Gardeła 2013a;108-10; Thäte 2007, 266-67; Cherryson 2010, 126-27). Furthermore, as Aspöck has suggested, the term 'deviant burial' can refer to the normative use of non-normative mortuary practices, making the term less productive than it could be $(2010,29)$. Our discussion makes use of the term 'deviant burial' to refer to non-normative funerary rites, keeping in mind the concerns raised by Aspöck. Such non-normative features can include, but are not limited to, spatial otherness, a notably different mortuary rite or practice, or a remarkable positioning of the body (Gardeła 2013a 108-10; Thäte 2007, 266-67). The importance of this distinction lies in the reservation of judgement and bias that would exclude individual expression in mortuary practice. 
scholarship, little work has been done to consider other textual sources in connection with punitive actions and attitudes or to compare these evidence sets.

\section{Judicial Violence in Law}

Among vernacular sources, legal texts make the most natural point of entry into the topic. Given the confines of this paper, we have opted to focus on Guta lag, ${ }^{7}$ Gulatingsloven, ${ }^{8}$ and Frostatingsloven ${ }^{9}$ on the Scandinavian side and on a small selection of contemporary English legal texts which are highlighted by Reynolds as referring to judicial violence and, potentially, deviant burial (2009, 251-61).

While few of the legal provisions discussed below survive in manuscripts dating to the period in question, strong internal evidence suggests that sections of these laws date to the Viking period and in some cases even earlier. ${ }^{10}$ Indeed, Folke Ström argued that the legal provisions dealing with capital punishment in Germanic societies are some of the most legally conservative in the corpus (Ström 1942, 11-13). These provisions were not immutable points of law, but we

${ }^{7}$ Guta lag, the "law of Gotlanders", is the medieval regional law from the largely independent island of Gotland (Peel 2015, 3). Guta lag survives in eight manuscripts, though only two medieval manuscripts preserve the original Gutnish and it is these that Peel focuses her translation and analysis on (2015, 3-5). The composition of Guta lag is still debated, though many argue for a composition date for the earliest manuscript of Guta lag between 1220 and 1250, with Peel arguing for a date around 1220; however, there is considerable internal evidence suggesting individual provisions in the law date to the early eleventh century and possibly even into the pre-Christianised Gotlandic past $(2015,21-5)$. Though often commented on for the ways that it stands apart from many mainland provincial Swedish laws (Peel 2015, 3-19), these differences make Guta lag an extremely useful source here, as it represents a Scandinavian law with a distinctly different outlook in terms of administrative structures and socio-legal influences, thus allowing for a broader analysis, more varied comparisons, and points of convergence which all the more interesting. For an extensive critical background to Guta lag, see Peel (2015, 3-29).

${ }^{8}$ Gulatingsloven, "the law of the Gulathing", is the medieval regional law that governed the area of the Gulathing in western Norway (Larson 1935, 6-11). While the oldest manuscripts date from around 1200, scholars argue that the provisions that make up the Olofstext of Gulatingsloven are believed to have already been set to writing possibly as early as the eleventh century (Riisøy 2009, 9-11). This makes Gulatingsloven an essential source for the present endeavour. For a detailed discussion of Gulatingsloven and its background, see Helle (2001, 17-23).

${ }^{9}$ Frostatingsloven, "the law of the Frostathing", is the medieval regional law that applied to the area of the Frostathing in northern Norway (Larson 1935, 7). The text of Frostatingsloven is only preserved in a copy of a medieval manuscript which was destroyed, making it difficult to date the text; however, scholars are in general agreement that some of the provisions are indeed very old (Tamm 2011, 15-16). For a full discussion of Frostatingsloven and Gulatingsloven and early Norwegian law in general, see Bagge (2010, 179-228).

10 See Peel (2015, 19-25) for discussion of this in Guta lag; Reynolds (2009, 23-29) for the Anglo-Saxon laws; Larson $(1935,7)$ for Gulatingsloven and Frostatingsloven; and Ström (1942, 8-13) for a more general discussion of these issues. 
aregue that the deeply transgressive nature of certain crimes would elicit judicial violence of one sort or another. In this way, we are less concerned with issues of continuity and preservation and rather focused on societal and legal norms and needs in a time of flux.

These provisions can yield a list of crimes held most heinous by the lawmakers of the society, shedding light on the needs and values of the population. ${ }^{11}$ For example, in Guta lag direct judicial violence was prescribed for only select crimes, while not compensating a killing in timely fashion could result in outlawry (Peel 2015, 209-10). In cases of adultery, rape, and theft, each was to be assessed for severity and the appropriate amount of judicial force was prescribed (Peel 2015, 209-25). Misappropriation of land worth three marks carried a single punishment of death, written literally as the convict's hals (neck), with the convict's wife losing her pew in church - no doubt a later provision (Peel 2015, 209-10). Slaves convicted of fighting freemen were also subject to a single punishment: two blows delivered to the slave for every one landed on the freeman (Peel 2015, 209-10). Theft was assessed by the value of goods stolen and recidivism (Peel 2015, 209-25). Stealing more than two öre, up to a mark of silver, was punished by branding before the assembly and a wergild payment (Peel 2015, 209-10). If the same thief committed even the slightest theft again, he was to be hanged; as was a thief who stole more than a mark of silver, even if only the first offence (Peel 2015, 209-10). By contrast, adultery was assessed by considering the types of people involved. Men committing adultery with an illegitimate daughter of a Gotlandic man or a non-Gotlandic woman, when caught in the act, was to be punished with the loss of a hand or a foot (Peel 2015, 209-10). If, however, the crime involved an unmarried Gotlandic woman he was to be placed in the stocks for three nights before losing his hand or foot (Peel 2015, 209-10). If the woman was married he was to pay with his life (Peel 2015, 209-10). Similarly, the rape of a married woman or a slave's rape of a Gotlandic woman were both punishable by death, though monetary settlements were allowed if the wronged party preferred (Peel 2015, 209-10).

These secretive crimes that shirked personal responsibility were uniformly detested across Scandinavia. ${ }^{12}$ Gulatingsloven and Frostatingsloven demonstrate similar interests. Capital punishment is prescribed for murder, as opposed to manslaughter (Larson 1935, 17-18, 129, 216, 257-62), and for theft (ibid, 165, 220-21). Beyond these, corporal punishment is prescribed for bestiality (Larson 1935, 57, 217) and the desertion of an alien thrall in the Frostatingsloven (ibid. 358), though flogging is the usual punishment for thralls (Larson 1935, 17, 24, 45, 48, 50, 167, $226,237,358,359)$. There are also many crimes for which these Norwegian laws prescribe outlawry, suggesting that breakers of the peace were unwanted in west Scandinavian society (Larson 1935, 15-18). For example, if a man charged with grave slander, ní ${ }^{13}$ failed a six-fold oath, Gulatingsloven stipulates he was to be outlawed (Larson 1935, 122). This allows the wronged party, if they wished, to kill the outlaw with impunity to redeem their own honour

11 For a broad discussion of legal environments of Viking-Age Scandinavia and England see Brink 2007 and Wormald 1999 respectively. For analysis of the gendered nature of law and punishment in medieval Scandinavia, see Ekholst (2014, 1-33).

12 For discussion, see Peel (2009, xxxi); Larson (1935, 17-18); and Ström (1942, 261). For background on how these crimes might fit into Viking-Age ethical contexts, see Bagge (2008, 10-11).

13 For a fuller discussion of níð, see Ström (1974). 
(Larson 195, 14-15). It is likely that lesser sentences were often agreed upon and, even in gravest circumstances, outlawry may have sufficed (Larson 1935, 17).

Discouraging theft, adultery, and rape in the strongest terms - by prescribing capital punishment - suggests that these judicial bodies, and many others across Scandinavia, sought to condemn specific types of behaviour: deviance which undermined local peace (Peel 2015, 1719). Theft, rape, and adultery are felt most profoundly at the local and familial level, suggesting that the kin-group, local relationships, and collective social stability were the most inviolable institutions to Scandinavians at this time. ${ }^{14}$

The diverse canon of English legal texts prescribing judicial violence can be turned to the same purposes, searching for hints of the values and institutions most protected by legal action (cf. Moreland 2003, 26-27). Clear patterns and similarities emerge. For example, theft, rape, assisting thieves or outlaws, fighting in the king's presence or breaking the king's peace, illegal minting activity, sorcery or wizardry, prostitution, plotting against the life of the king, and desertion could all carry violent punishments under various kings in the Anglo-Saxon period (Reynolds 2009, 251-61). Given the immensity of the English legal corpus, compared to Scandinavia, it is not surprising that at various times, under different rulers, and in different kingdoms many of these crimes warranted fines instead of or alongside a violent punishment often determined by the severity of the crime as assessed by the judicial body in each case. ${ }^{15}$ While theft and rape were considered capital offences, adultery, in contrast with Gotland, carried a lesser penalty (Reynolds 2009, 170, 251-61; Peel 2015, 209-10). Victoria Thompson demonstrates that only from Athelstan (924-939) onward is execution listed as an automatic punishment for a crime, and even then only for select few cases $(2004,181)$. This should be viewed as a slight shift in legal perspective. Execution was certainly practiced before Athelstan's time, however first recourse was to non-lethal settlements (Thompson 2004, 181).

The catalogue of capital offences in England extends beyond the morally taboo, incorporating acts that undermined the king's power and the realm's peace. Actions such as fighting in the king's presence or plotting against him directly put the safety of the ruler in jeopardy, threatening the stability of the realm (Reynolds 2009, 23-29). Illegal minting, assisting thieves and outlaws, breaking the king's peace, and desertion are telling inclusions as they do not threaten the king's safety but rather undermine his authority in the realm (Reynolds 2009, 2329). Thus the main body of crimes warranting the most extreme punishments are those that transgress against the king and the kingdom. This evidence suggests that it was the king and his force in the realm that were of highest import to the empowered population in England at this time.

A number of offences against the aims and institution of the church in England also called for violent punishment, particularly in the late tenth and early eleventh centuries. Wizardry, sorcery, and prostitution, all denounced vehemently by the church at the time, are significant inclusions (Reynolds 2009, 23-29; Thompson 2004, 180-84). Given that these laws come from the codes attributed to Wulfstan II, who apparently sought penal leniency and particularly an avoidance of

${ }^{14}$ For a recent discussion of these social structures and their operation in Viking-Age societies, see Jón Viðar Sigurðsson (2017)

15 For the varying degrees of severity in these crimes see Reynodls's hand-list (2009); also Wormald (1999). 
capital punishment, ${ }^{16}$ these crimes being counted as capital offences speaks to the church's view on their severity. The king, by marking these with lethal punishment, bolstered his own position vis-à-vis the church by declaring himself as the champion of its agenda. Those who acted in opposition to its stance on these issues now also acted against the king.

These texts also shed some light on how judicial violence was administered. The laws of both Gotland and England mention the practice of branding and marking but do not specify how these were carried out (Peel 2015, 74, 200-01; Reynolds 2009, 251-61). The Norwegian laws state that floggings were administered but once again provide little further detail (Larson 1935, 45, 48, 50, $167,226,237,358,359)$. The laws prescribing maiming often stipulate that the convicted party should pay with the loss of a hand or a foot, although eyes, ears, noses, and other body parts are also mentioned at various times (Reynolds 2009, 23, 251-61; Larson 1935, 57, 217, 358; Peel 2015, 209-10). It is often presumed that these were struck off with a sword or an axe, but the nature of the instrument is not specified.

Where execution is prescribed we can learn a little more. For example, Guta lag's references to execution usually stipulate that one pays with their 'life' or their 'neck' (Peel 2015, 209-10). Despite this, in the case of committing a second theft or stealing more than a mark of silver, the law specifies that the convicted party is to be hanged (Peel 2015, 209-10). This is the only place in Guta lag that a form of execution is overtly stipulated (Peel 2015, 174). While the convicted party is still to be killed by judicial decree, hanging appears to have been considered a particularly 'shameful' form of execution (Peel 2015, 173-74, 209-10). Peel uses examples from contemporary Swedish provincial laws to show that female thieves were spared this embarrassment, instead being put to death in other ways (2015, 174; Ekholst 2014, 68-75). Calling on early-modern evidence, Reynolds argues that, from a Christian perspective, hanging corpses can be conceived of as caught between heaven and earth, suspended in a state of shameful otherness $(2009,248-49)$. While this suspended liminal state may have had ideological significance to English Christians, though the chronological gap in evidence is worth noting, it is doubtful that it held the same significance to pre-Christian or even Christianizing Gotlanders. ${ }^{17}$ It is possible that the stipulation of hanging is a later addition to the law, but Peel's note, that Guta lag is the only provincial law in Sweden to specify hanging for recidivist theft despite an earlier Germanic framework for it, suggests that something else may be operating here $(2015,174$; Ström 1942, 115-61). Ström convincingly shows that a very strong pre-Christian shame element permeated the practice of hanging $(1942,161)$, which may be the reason that Swedish lawmakers were reluctant to expressly prescribe hanging, making this Gotlandic provision one of the few extant exceptions. ${ }^{18}$ Hanging is not overtly prescribed in the Norwegian laws examined here, with both the Gulatingsloven and Frostatingsloven opting instead for the use of a headsman where any execution method is stipulated (Larson 1935, 129, 165, 262-63, 398). ${ }^{19}$

16 For a discussion of Wulfstan's role in and views on lawmaking, see Thompson (2004, 180-95) and Wormald (1999, 352-5).

17 For a fuller discussion on conversion and Christianization, see Abrams 2000.

18 Peel discusses how Gotland consistently and intentionally distinguishes itself from the rest of Sweden at this time (2015, xii-3). For more examples of overt stipulations for judicial hanging and their contexts, see Dutton (2016, 137-50).

19 For a thorough discussion of hanging in pre-Christian Scandinavia, see Dutton (2016). 
While the English laws are curiously silent about the practice of hanging (Reynolds 2009, 251-61), some are in more descriptive than their Scandinavian counterparts. For example, in Athelstan's laws thieves that were free women were to be thrown from a cliff or drowned, those that were male slaves were to be stoned by twenty-six slaves (Reynolds 2009, 253); and those that were female slaves were to be burned by twenty-six female slaves bringing three logs apiece (ibid, 254). The laws of Edgar say that a man whose statement was proved false by witnesses would forfeit his head, suggesting decapitation (Reynolds 2009, 257), and Æðelred II also called for a head in payment for recidivism (ibid, 257). Beyond this, though, the laws often state offenders would forfeit their lives or were to be slain (Reynolds 2009, 251-61). This is problematic, possibly suggesting a different ideology toward hanging in England than we would expect from Reynolds's statement above. Such ambiguous wording may have been used intentionally to respect local traditions and desires as to how to deal with criminal deviants (Thompson 2004, 182). It is also possible that hanging was so ubiquitous that it did not require direct stipulation (Whitelock 1952, 44). We can turn to other texts to test these possibilities further.

\section{Historical Comparisons}

A point of comparison is provided by the Anglo-Saxon Chronicle (hereafter ASC) which, although written from an English perspective (Jorgensen 2010, 1-4), seems to contain contemporary descriptions of both English and Scandinavian judicial violence. These descriptions would have to have been presented in an accurate, or at least plausible, context in order to ring true with a legally- and politically-active audience. The matter-of-fact phrasing with few contextualizing details makes it difficult to differentiate between killing and judiciallysanctioned execution, as well as between self-imposed or extra-legal exile and outlawry. ${ }^{20}$ For example, Elizabeth van Houts highlights the vague terminological distinctions between Old English adrifan, fordrifan, afleman, and utian, ${ }^{21}$ as well as the ultimately Old Norse derived utlagian, ${ }^{22}$ which can pose problems (2010, 13-17). More difficult are the many cases where it is simply stated a person was slain. However, where this occurs in association with other seemingly legal happenings, judicial motivations, with appropriate caveats, can be explored.

Several entries stand out as candidates for testimony to judicial violence. The entry for 897 , for example, describes Danish raiders who are captured, taken to Winchester, and hanged by the king's order (Swanton 1996, 89-90). This passage is remarkable for several reasons. First, it describes hanging, which is a surprising rarity in the ASC. Second, instead of expected combat outcomes, like a parley, routing, or killing on the spot, these raiders are brought before the king at a significant power-seat, suggesting an attempted judicial solution. Third, Alfred's laws, which include lethal provisions for theft and breaching the king's peace, state that in grievous cases the transgressors should be brought before the king for judgement (Reynolds 2009, 251-52). This was likely the protocol followed here.

${ }^{20}$ For a fuller consideration of the linguistic confounds of the chronicle, see Pons-Sanz (2010).

21 All of which signify both judicial and extra-judicial forms of exile.

22 Although a later term, possesses a specifically legal semantic field. 
It is not until 993 that we again see evidence for judicial violence at the king's behest, with the bare comment 'het se cyng ablendan AElfgar' (Earl and Plummer 1965, 127). ${ }^{23}$ The entry for 1002 contains two possible instances. The first is the banishment of ealdorman Leofsige for his apparently unlawful slaying of Ælfic, the king's high-reeve (Swanton 1996, 133-34). Wormald shows that a precedent existed for the judicial outlawing of high-ranking individuals during Æðelred II's reign (1999, 320-45), which suggests that this episode indeed describes judiciallyprescribed exile. The second instance, near the end of the entry, describes the St Brice's Day Massacre (Swanton 1996, 134-35). Æđelred orders the killing of all Danes in England for an apparently seditious plot (Swanton 1996, 135). The historical details of this event remain elusive but an interpretation to the effect that the king responded with judicial violence is supported by contemporary laws which punish plots against the king with forfeiture of life (Reynolds 2009, 259).

In the 1006 entry (Swanton 1996, 136) it is relayed in uninterrupted succession that Wulfgeat was deprived of all his property, Wulfheah and Ufegeat were blinded, and ealdorman Ælfelm was slain. The first is highly suggestive of legal activity, as many of Æðelred's laws prescribe the confiscation of a convicted party's holdings (Reynolds 2009, 257-59). Although the blinding and slaying are less suggestive in the absence of contextualizing detail, the juxtaposition with the repossession provides a possible context, keeping in mind that Æðelred's laws often prescribe mutilation and execution (Reynolds 2009, 257-59). ${ }^{24}$ Furthermore, the three events exhibit a logical progression toward a more complete violent removal of the convicted individual from power-structures.

The 1014 entry (Swanton 1996, 144-45; Earl and Plummer 1965, 145) specifically uses the term utlagian to describe the banishment of Danish kings from England (van Houts 2010, 1317). It also describes how Knútr, now outlawed, took the hostages his army had received securing Sveinn's reign, landed them at Sandwich, and cut off their hands and noses. ${ }^{25}$ While initially this might not seem like judicial violence, Knútr's restraint in keeping the hostages alive, as well as his landing them at the legally and politically important site of Sandwich, implies a complexity to these actions. We suggest this was perhaps an attempted international legal solution to the national oath-breaking of the English who accepted and then rejected Knútr's bid for the throne. His choice to remove very visible appendages would have left a powerful reminder to the English population that oath-breaking, a serious crime in both legal spheres, was not tolerated by him. This reading is made more pertinent when we consider that these hostages were likely men of influence in English society.

In the 1015 entry we are informed that ealdorman Eadric slew Siferth and Morcar (Earl and Plummer 1965, 145-46; Swanton 1996, 145-46). The annalist clearly feels this was unjust, but King Æðelred seized the possessions of Siferth and Morcar, including Siferth's wife. In contrast, Eadric goes unpunished. Eadric possibly followed Æðelred's orders here, but these slayings appear different from judicial violence since they apparently occurred in Eadric's chambers, not

\footnotetext{
23 'the king ordered Ælfgar to be blinded,' our translation.

24 Swanton suggests ÆElfelm's death may have been subject to some intrigue, but concludes that these events relate to legal punishment (Swanton 1996, 136).

25 MSS C and D note that ears were also removed (Swanton 1996, 145).
} 
at the Oxford assembly: hardly an official setting. ${ }^{26}$ This extra-judicial royal violence takes on new importance when considered alongside the 1014 entry which, recounting Æðelred's return to England, notes that the clergy and laity of England wished him to return but only if he governed more justly than he did before. ${ }^{27}$ This statement suggests that Æðelred may have occasionally circumvented his own laws in the past and moreover, given these slayings, may not have been holding up his end of the bargain, resorting to non-judicial violence to maintain his position.

Despite the characteristic lack of contextualizing details in the $A S C$ entries, some point to judicially-prescribed outlawing, maiming, and execution. Considering these entries in the context provided by the legal texts is revealing: we glimpse elements of the historical legal systems in action (897): in some legal cases not one but many parties were punished using judicial violence (897 and 1002); also, royally- and judicially-prescribed violence are not synonymous (1015).

\section{Literary Comparisons}

Contemporary poetry contains further clues as to how judicial violence functioned. Exploring the peculiarities of the execution described in the Old English Juliana, ${ }^{28}$ Dorothy Whitelock (1952, 144) sought elements of English judicial practice, highlighting the poem's detail that executions were expected to be conducted in liminal spaces and that swords could be used for these purposes (1952, 140-45), though Thompson observes that a variety of methods were likely used, depending on local traditions $(2004,182)$. Much like Juliana, Judith $^{29}$ also contains a decapitation for wrongdoing, though admittedly the law being enforced is hardly an earthly one and neither is the judge. There nonetheless seems to be a semi-judicial dooming of the accused and even an invocation in the name of divine law, as if to make the condemnation more official (Bradley 1995, 498). Furthermore, the head of the accused is displayed to the people as proof of the deed and as a final shame to the condemned, lining up very well with the elements of display noted above (Bradley 1995, 500). While both of these texts rely heavily on Latin sources and a sense of antiquity, they provide hints toward English judicial processes and suggest that an exploration of more native sources is a productive exercise.

Beyond decapitations, English literary texts exhibit a keen interest in hanging, such as a passage of Beowulf where several prisoners of the Swedish-Geatish war were put to death by the

26 This episode smacks of political, not judicial, intrigue. The entry details how Edmund, the king's son, acting against Æðelred, marries Siferth’s widow and claims his estates (Swanton 1996, 146). For a further discussion of Edmund's actions, see Lapidge (Lapidge and others 2014, 165). Any potential dispute is overshadowed in the entry by the coming of Knútr's army; however, it is telling that Edmund and Eadric are unable to join forces to combat the invasion, due to an apparent plot by Eadric to betray Edmund (Swanton 1996, 146). As for the distinction between official and private spaces, and the activities undertaken in each, see Walker (2011, 221-235).

27 See Earl and Plummer (1965, 145): 'gif he hi rihtlicor healdan wolde ponne he ar dyde.'

28 Juliana is contained in the Exeter Book (fol. $65^{\mathrm{b}}-76^{\mathrm{a}}$ ) which is dated to the latter half of the tenth century (Bradley 1995, 199).

${ }_{29}$ Contained in Cotton Vitellius A xv, the same manuscript as Beowulf, the pertinent sections of which date to the latter tenth or earlier eleventh centuries (Bradley 1995, 405). 
sword - legal or extra-legal context remains unclear - and others on the gallows. The latter are left for the carrion beasts (Bradley 1995, 488), in a prolonged display similar to those considered above. Maxims II tells us that a 'criminal must hang and fairly pay the recompense because he previously committed a crime against mankind' (Bradley 1995, 514). ${ }^{30}$ More noteworthy is the vivid image portrayed by The Fortunes of $\mathrm{Men}^{31}$ describing the corpse of a hanging criminal:

Sum sceal on geapum galgan ridan, seomian at swylte, oppat sawlhord, bancofa clodig, abrocen weorpeð.

Par him hrefn nimep heafodsyne, sliteð salwigpad sawelleasne; noper he py facne mag folmum biwergan, lapum lyftsceapan, feores orwena, blac on beame bideð wyrde, bewegen walmiste. Bið him werig noma! (Krapp and Dobbie 1936, 154-55) One shall ride the high gallows and upon his death hang until his soul's treasury, his bloody bone-framed body, disintegrates. There the raven black of plumage will pluck out the sight from his head and shred the soulless corpse - and he cannot fend off with his hands the loathsome bird of prey from its evil intent. His life is fled and, deprived of his senses, beyond hope of survival, he suffers his lot, pallid upon the beam, enveloped in the mist of death. His name is damned. (Bradley 1995, 342)

This excerpt reveals an important detail. Though the English may have utilized trees for some hangings (Ström 1942, 115-61), this poem mentions a constructed 'gealga', gallows.

Furthermore, while the Old English beam is often used to refer to trees, in this case it most likely refers to a wooden beam of a felled timbre making up the arm of the gealga (Bradley 1995, 342; Clark Hall 2007, 34). ${ }^{32}$

As observed by Reynolds, Ström, and Peel above, these extracts all describe victims of hanging being left on the gallows after they died (Reynolds 2009, 23-27; Ström 1942, 115-61; Peel 2015, 174). The Fortunes of Men particularly suggests that the convicted would have hung for some time, making a shocking spectacle indeed (Bradley 1995, 342). Comparable is another excerpt from Beowulf.

${ }^{30}$ Preserved in Cotton Tiberius B i (fol. $115^{\mathrm{a}}-115^{\mathrm{b}}$ ), dated between the eleventh and twelfth centuries (Bradley 1995, 512). The Old English, 'wearh hangian, fagere ongildan paet he aer facen dyde manna cynne', is noteworthy as, while 'cer... dyde' often simply denotes past action, the inclusion of this complex alongside the intensely pejorative 'wearh' warrants considering the possibility that this may relate to the later English legal treatment of recidivism, which grew increasingly strict in Æðelred II's laws (Reynolds 2009, 257-61), especially given the manuscript's dating.

31 Also preserved in the Exeter book (fol. 87 $-88^{\mathrm{b}}$ ) (Bradley 1995, 341).

32 Though less common, beam refers to felled timbers elsewhere in the corpus of Old English poetry, such as in line 158 of Maxims I (Bradley 1995, 350). The fact that Maxims I follows immediately after The Fortunes of Men in the Exeter book justifies this consideration of the expanded semantic field here. 
Swā bið gēomorlīic gomelum ċeorle

tō gebìdanne, pat his byre rīde

giong on galgan. Ponne hē gyd wrece,

sārigne sang, ponne his sunu hangað

hrefne tō hrōðre, ond hē him helpe ne moeg

eald ond infrōd änige gefremman,

symble bið gemyndgad morna gehwylce

eaforan ellorsīð; $\bar{o} \partial r e s$ ne ġ̀með

tō gebìdanne burgum in innan

yrfeweardas, ponne se ān hafað

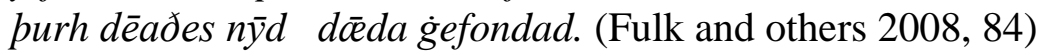

So too it is a melancholy thing for an old man to experience, that his young child should swing upon the gallows. Then he will give vent to lamentation and agonized plaint, when his son is hanging at the raven's pleasure and he, aged and senile, cannot afford him any help. Always each morning his son's departure to another place is remembered afresh; he does not care to wait for another heir within his dwellings now that this one has experienced the full consequence of his actions through pain of death. (Bradley 1995, 475-76)

Although Scandinavian poetry focuses more on outlawry than execution, as expected from the legal analysis above, the latter is far from absent. Some depictions however seem to be entirely for literary effect, such as most of those in the cycle of the Volsung poems in the Poetic Edda (Dronke 1969; Larrington 1996). Ranging from the infamous 'blood eagle' (Larrington 1996, 283), dying in a pit of serpents, to trampling by horses, to beating hearts cut out, many of the executions depicted are shocking, evocative, and ultimately historically unlikely (Dronke 1969, 7, 9, 88-89, 146, 161, 164; Larrington 1996, 156), as we would expect of largely mythological narratives (cf. Clark 2012, 18-20; Niles 2007, 63; Lindow, 2002, 40-44). That said, even extreme depictions may still provide valuable insights.

Particularly in the Volsung poems, in each case the executions fall into a semi-judicial setting, with the punishments following wrongdoing against a powerful noble. The slayer of Sigmundr has the blood eagle carved on his back (Larrington 1996, 156); Gunnarr is cast into a pit of serpents (Dronke 1969, 9) and Högni has his heart cut out for refusing to serve Atli's purposes (Dronke 1969, 8, 89); and Svanhildr is trampled by horses following an accusation of adultery (Dronke 1969, 146, 161). Each execution, however fantastical, is constructed as a punishment that fits the 'crime', as least as perceived by the party passing the judgement and carrying out the sentence. The same can be said of the overtly mythological exchange between Týr and Fenrir where Týr puts his hand up as collateral in their deal and subsequently loses it (Larrington 1996, 90). Despite his false oath, a crime we are warned about elsewhere in the Poetic Edda (Larrington 1996, 170), his ready payment seems to be considered fair (Larrington 1996, 91). The one dissenter is Loki in Lokasenna, but his claim that Týr deals falsely immediately precedes his admission that he never paid Týr compensation for sleeping with his wife (Larrington 1996, 91). Even this exchange suggests a semi-legal environment for these extraordinary punishments.

Beyond these outliers, the poetic evidence for Scandinavian judicial violence is comparatively matter-of-fact. A number of hangings are detailed in the skaldic poetry preserved in Ynglinga saga, which presents them as at least judicially-acceptable ways of seeking compensation for wrongs in the distant past (Finlay and Faulkes 2011, 6-47). For example, in chapter 19 we learn that Skjálf hangs King Agni to avenge her father's death (Marold 2012, 22) 
and in chapter 24 Jörundr, Yngvi's son, is hanged to avenge his killing of Gýlaugr's father Guðlaugr (Marold 2012, 28). On the other hand, the initial killing of Guðlaugr is troubling, for Yngvi's sons hang him without any compensatory motive (Poole 2012, 202-03). One could speculate that hanging, here, operates merely as a way to put enemies to death after battle. Considering, however, that the motif of hanging is not preserved in any poetry from the rest of the early sagas of Heimskringla until Óláfs saga Tryggvasonar, ${ }^{33}$ these descriptions may be vestiges of a semi-legendary past in which vengeance and forceful expansion were commonplace as Scandinavia went through the throes of primordial state-building. This makes the use of hanging in these contexts functionally similar to the execution methods in the mythology.

Beyond this, the verses depicting hanging in Ynglinga saga are actually rather unhelpful, relaying little more than that someone was hanged. Gallows, where mentioned, are described through kennings, typically involving horse or tree elements (Finlay and Faulkes 2011, 6-47), which precludes identifying any features of them. By contrast, the verses contained in Hemskringla increasingly refer to outlawry, probably a more historically-supported practice. Consider for example, the lausavísa, attributed to Hildr Hrólfsdóttir nefju, preserved in chapter twenty-four of Haralds saga ins hárfagra.

\section{Hafnið Nefju nafna;}

nú rekið gand ór landi

horskan holða barma;

hví bellið pví, stillir?

Illts við ulf at ylfask

Yggs valbríkar slíkan; muna við hilmis hjarðir

hogr, ef renn til skógar.

You renounce $\{$ Nefja's namesake [= Hrólfr]; now you banish the wolf, the wise brother of freeholders, from the land; why do you risk that, lord? It is dangerous to threaten such a wolvish enemy $\{$ of the Yggr <= Óðinn> \{ of the slain-plank\} [SHIELD > WARRIOR (= Haraldr)]; he will not be gentle with the ruler's herds if he runs to the forest. (Gade 2012, 139)

The stanza is a cautionary comment that although outlawry removes a transgressor from the normative society's daily operation it can actually empower the outlaw to act out against that same society.

The lausavísa attributed to Torf-Einarr Rognvaldsson in chapter thirty-one of Haralds saga ins hárfagra is more helpful, conveying the relationship between a crime, a punishment, a geographic location, and a ruler.

Margr verðr sekr at sauðum seggr með fogru skeggi,

${ }^{33}$ Hanging is occasionally mentioned in the prose of Heimskringla, but our discussion here, focused on near-contemporary texts, only examines the more securely dateable poetic evidence. For further discussion of royally-sanctioned judicial execution in Heimskringla, see Ruiter (2014). 
en ek at ungs í Eyjum

allvalds sonar falli.

Hatt segja mér hollðar

við hugfullan stilli;

Haralds hefk skarð i skildi

- skala ugga pat - hoggvit.

Many a man with a handsome beard is convicted for sheep, but I [am convicted] for the death [of the young son of the mighty ruler [= Hálfdan] in the Islands [Orkney]. Freeholders say there is danger for me from the resolute ruler; I have cut a notch in Haraldr's shield; I shall not fear that. (Poole 2012, 133)

Thus, during Haraldr's reign, unlawful killing of livestock could result in outlawry. A section of Frostatingsloven mirrors this, stipulating that unlawfully damaging cattle could result in outlawry (Larson 1935, 273). Given livestock were used as standard units of value (Larson 1935, $151,237,322)$, the loss could be used to assess of the severity of the transgression.

\section{Synthesizing the Textual Evidence}

Taken together, this evidence demonstrates two distinct punitive systems, tailored to suit the specific socio-legal needs and norms of their respective societies. ${ }^{34}$ This analysis suggests that the English system of judicial violence assessed crimes for severity through royal involvement or representation, had a complex and varied hierarchy of judicially violent punishments, often using elements of display in those punishments. By comparison the Scandinavian evidence points to an equally sophisticated system in its legal thoroughness, favouring outlawry over execution, though both were evidently utilized.

The legal and historical evidence is often unclear on the methods of execution, but evidence abounds in the Scandinavian and English traditions to point to decapitation and hanging being used in both regions. Ström confirms this, saying that both cultures had an ancient framework for both practices (Ström 1942, 115-61, 162-71). Both regions, however, also demonstrate a deliberate vagueness in their laws describing judicially-violent punishments. ${ }^{35}$ This could be an intentional effort to respect more varied local traditions of execution (Ström 1942, 115-61, 16271; Thompson 2004, 182).

\section{Archaeological Evidence}

While these depictions of judicial violence are informative in their own right, a richer reading is possible when the textual sources are augmented with archaeological evidence (see Moreland

\footnotetext{
${ }^{34}$ These socio-legal needs and norms, of course, being predominantly controlled and reinforced by the empowered members of the society. For a broader perspective on these structures in early Scandinavia, and a short overview of research on the legal aspects of this topic, see Brink (2015 and 2014). On the English side, Lambert (2017) provides an up to date examination of kingship, control, and legal development, see especially chapter 9 for an overview (2017, 349-364).

35 For example, consider the paradigmatic use of 'neck' and 'head' as compensatory payments.
} 
2003, 26-27). Here literary and archaeological evidence are considered in tandem in order to synthesize an English context for judicial violence. The same will then be undertaken for Scandinavia, before we compare these contexts to reflect more holistically on how judicial violence operated in these societies.

The archaeology of non-normative mortuary rites and judicial violence in Anglo-Saxon England has seen extensive study in recent years (e.g. Buckberry and Hadley 2007; Buckberry 2008; Semple 1998; Klevnäs 2016a, 2016b; Aspöck 2011, 2015). Most notably, Andrew Reynolds (2009) has provided a wide-ranging thesis which shapes much of current debate and provides the basis for much of the analysis below. Given the limits of archaeological evidence, current studies mostly consider executions and associated mortuary practices. ${ }^{36}$ Evidence of the punishment of outlawry, of course, is archaeologically invisible and is thus largely absent from this scholarship. ${ }^{37}$

Mortuary evidence serves to demonstrate the level to which such violence was integrated into English society. Reynolds in particular notes a spatial othering in the distribution of graves exhibiting signs of deviant burial (Reynolds 2009, 56-60). Hadley provides some examples of distinct graves that, when found within 'normative' cemeteries, are located in peripheral contexts (Hadley 2010, 102-06). The larger pattern suggests that, especially in the Viking Age, social others, particularly the victims of judicial violence, in England would often be interred in cemeteries unto themselves. These tend to coincide with boundaries and other liminal spaces (Reynolds 2009, 56-60, 155-57). Examples include Sutton Hoo (Suffolk), Gally Hills (Surrey), and Walkington Wold (East Yorkshire), all of which are situated in immediate relation to contemporary hundred boundaries (Reynolds 2009, 155-56; Buckberry and Hadley 2007). In many cases these graves were likely marked in some way, given the remarkable absence of evidence for grave disturbance (Reynolds 2009, 188-90). The inclusion of charcoal in a selection of graves at Guildown (Surrey) may have served as such a marker, warning potential gravediggers, legitimate or otherwise, of the burials beneath (Reynolds 2009, 140-41). ${ }^{38}$

Beyond the association with boundaries and liminal spaces, there is a high correlation between these cemeteries and major land and water routes (Reynolds 2009, 155). There is also a notable relationship between execution cemeteries and earthworks of various types (Semple 1998). Most of these are pre-existing, such as at Meon Hill (Hampshire), Staines (Middlesex),

${ }^{36}$ Reynolds considers the various aspects of English deviant burial to manifold effect and considers each in relation to the Christianization process (Reynolds 2009, 34-60). Portions of Reynolds's findings have been problematized (Lambert 2012, for example) and nuanced further (Klevnäs 2016a, 2016b and Aspöck 2011, 2015, for example), however, much of his study remains convincing, particularly when it comes to individual graves and well-documented 'execution cemeteries' which we shall focus our attention on.

${ }^{37}$ Fruitful work has been done to examine possible outlaw hideouts, such as Surtshellir in Iceland (Guðmundur Ólafsson and others 2010); however, these studies can only demonstrate that these sites were occupied by individuals removed from society. Furthermore, given the remarkable differences in nearly contemporaneous sites in the same region, there are still too many unanswered questions regarding this evidence set and no such finds have been extensively studied in mainland Scandinavia or England.

${ }^{38}$ For a helpful overview of some examples of contemporary grave marking, see Sayer (2013, 139). 
and Dunstable (Bedfordshire), though some seem to have been purpose-built, as at Chesterton Lane (Cambridgeshire), Sutton Hoo (Suffolk), and possibly Crosshill (Nottinghamshire). These efforts suggest that, despite their liminal nature, these sites were intended to be visible (Reynolds 2009, 156-57).

Using a combination of archaeological, literary, and toponymic evidence, Sarah Semple has convincingly argued for contemporary supernatural beliefs surrounding ancient earthworks (1998, 111-13). Such traditions make them particularly appropriate contexts for the burial of the deviant dead (Semple 1998, 111-14). Regardless of whether these places were viewed as conceptually and spiritually removed from the land of the living (Reynolds 2009, 250), as supernaturally empowered to torment the souls of the interred, or as facilitating the apotropaic disposal of the powerful dead, any such beliefs would make ancient earthworks a natural choice for disposing of deviants (Semple 1998, 111-13, Reynolds 2009, 247-50).

Execution cemeteries frequently correspond with a number of relevant toponymic elements, such as gealga, 'gallows', 39 and peof, 'thief' ${ }^{40}$ (Reynolds 2009, 101-03, 128-30, 137-38, 222-27). These toponyms suggest that some of the cemeteries associated with these earthworks may have been sites not only for the disposal of the deviant dead but also actual sites of execution (Reynolds 2009, 247-50). These associations, together with the probable construction and reappropriation of earthworks, is indicative of a dynamic, highly sophisticated judicial landscape, in which judicial violence played a key part (Reynolds 2009, 247-50).

Beyond their place in the wider landscape, excavations of these execution cemeteries frequently reveal graves that are remarkable in terms of internal arrangement, body position, and evidence for post- or perimortem practices (Reynolds 2009, 152-79). For example, in English execution cemeteries graves tend to be arrayed in accordance with local topography, rather than following the governing principles common to normative cemeteries (Reynolds 2009, 157-59), though Klevnäs and Aspöck have both problematized some of the previous discussion of normative principles in English mortuary practices (Klevnäs 2016b; Aspöck 2011, 2015). Nonetheless, while many execution burials are shallow and rudimentary, a number do show evidence of stoning, ${ }^{41}$ weighting, trussing, or binding of corpses (Reynolds 2009, 157-79). In fact, despite criminal deviants being relegated to the lowest levels of society, in some cases their disposal would probably involve more effort than a normative burial (Reynolds 2009, 159). ${ }^{42}$

In the later Viking Age, prone burial in England may have also be used to distinguish the deviant dead (Reynolds 2009, 160-61). Reynolds cites fifty-one occurrences from seventeen sites, noting particular examples that were distinguished with other signs of deviant burial (Reynolds 2009, 160-61). Such burials - like graves 34 and 39 from Stockbridge Down

39 Such as Galley Hill (Bedfordshire) and Gally Hills (Surrey).

40 Such as those near Crosshill (Nottinghamshire).

41 The practice of intentionally incorporating stones into the inhumation, whether placed on or around the corpse or, where evidence is available, violently thrown pre-, peri-, or post-mortem. For a fuller discussion of stoning and its context in the early medieval world including comparative analysis, see Gardeła (2017, 160-204).

42 Consider for example the anomalously deep graves at Guildown (Surrey) (Reynolds 2009, 140-41) or burials at Roche Court Down (Wiltshire) that were sealed with a layer of flints (Reynolds 2009, 148-49). For a comparative example of flint deposits in graves, see the discussion around Winnall II in Klevnäs (2016a, 188), and especially Aspöck (2011; 2015). 
(Hampshire) (Reynolds 2009, 161) - may hint at a pre-Christian apotropaic practice of guarding against the 'powerful' dead similar to ideas put forward by Semple (Semple 1998, 111-14).

A number of graves indicate that individuals, or parts of them, were displayed, some for prolonged periods, and there is evidence at a number of sites for the use of heafod stoccan or 'head stakes' (Reynolds 2009, 159-69). Walkington Wold (East Yorkshire) is a particularly good example of a site that seems to have commonly displayed decapitated heads, with ten of twelve individuals having been buried without their heads and eleven buried at the centre of the mound, four with mandibles, and seven without (Reynolds 2009, 169). ${ }^{43}$ Of course, not all proposed examples of deviant burial incorporating display are as remarkable as Walkington Wold and skepticism should be exercised in cases without detailed taphonomic analysis. Nonetheless, archaeological evidence for the display of heads in England at this time is convincing.

Thus we return to the issues of visibility and display highlighted in our investigation of the textual sources. While the threat of execution and judicial violence may have been enough to keep most in line, keeping the execution sites visible to the public and openly displaying the executed could only strengthen the sentiment.

In comparing the textual and archaeological evidence, the sophistication of the English system of judicial violence becomes clear. Both evidence-sets independently illustrate the liminal nature of execution sites show that both hanging and decapitation were likely practised. Archaeological evidence and topography suggest that execution sites and cemeteries made up an important part of the physical and judicial landscape, while the literary, legal, and historical texts show that judicial violence had also permeated deep into the cultural landscape (Reynolds 2009, 160-79; Thompson 2004, 180-95). Even Reynolds's suggestion that visibility was an important component of the function of execution sites is mirrored in the textual accounts and helps to inform our readings of some of the laws (Reynolds 2009, 157). For example, a law that is continually recycled between English rulers prescribes that moneyers who mint false or base currency should have a hand cut off and fastened to the mint. The sentiment here is clearly consistent with the display of decapitated heads or an executed body: to make a visible example of the wrongdoer.

More recently, the discovery of around fifty bodies in a pit at Ridgeway Hill in Dorset provides an example of another treatment of visibility and forcibly removed body parts (Chenery and others 2014, 43-44). Seemingly the result of a single execution, all the bodies in the pit had been decapitated and the heads, including mandibles, were piled on the southern edge of the pit (Chenery and others 2014, 43-44). The bodies of the victims were seemingly shown less attention and were deposited with no apparent organized effort around the pit, often overlapping (Chenery and others 2014, 43-44). The intentional piling of the decapitated heads seems to echo the elements of display that have been discussed above and the positioning of the site in the surrounding landscape certainly fits the pattern of other execution sites. The current interpretation of the site is that it holds the executed remains of a crew of failed raiders of mixed backgrounds who met their end on an ill-fated sortie in English territory between the late tenth and early eleventh centuries (Chenery and others 2014, 50-51). Though markedly different from the display component of a site like Walkington Wold, the treatment of the postmortem remains

${ }^{43}$ For discussion of the weathering process of the remains at Walkington Wold and wider evidence of heafod stoccan in archaeology and charter evidence, see Buckburry and Hadly (2007). 
at Ridgeway hill helps to reemphasize the flexibility of the English system of judicial violence when it came to mechanisms of execution and deposition of the dead and stress the importance of site and visibility in these proceedings.

Taken together, this evidence suggests the punitive system of Viking-Age England was remarkably integrated into the lived landscape. Laws dictated by the king outlined appropriate behaviour, officials oversaw the administration of justice in cases of deviance, punishment was delivered at specific, even purpose-built, sites, and the convicted were punished and publicly displayed, discouraging future infractions. This final step actually created a feedback loop, suggesting an effort by contemporary lawmakers to condition out undesirable behaviour in the population. Analysed in this way, both textual and archaeological evidence point to a highly regimented, top-down framework for judicial violence in Viking-Age England.

Leszek Gardeła and others have conducted similar investigations in Scandinavia ${ }^{44}$ but the picture is more tentative. ${ }^{45}$ In particular, the considerable variety of normative mortuary rites makes the graves of social and criminal deviants exceedingly difficult to identify with certitude (Gardeła 2013a, 99). Nonetheless, several burials have been identified that, even against the broad spectrum of Viking-Age Scandinavian mortuary practice, stand out (Gardeła 2013a, 99; Gardeła 2013b, 106-44). Though Gardeła (citing Thäte 2007, 266) urges us to remember that no single explanation can be ascribed to all burials showing signs of deviation from the norm, it is a productive exercise to keep execution and maiming in mind while considering a selection of the evidence presented by him (Gardeła 2013a, 109).

Unlike in the English evidence considered above, no exclusively deviant cemeteries have been discovered in Scandinavia to date, leading Thäte and Gardeła to postulate that nonnormative individuals were perhaps not viewed as complete outcasts and were allowed burial within communal cemeteries (Gardeła 2013a, 109-10; Thäte 2007; 267-72). Gardeła suggests that many of the deviations in Scandinavian mortuary practice at this time may have multiple meanings, some of them related to ritual or religion (Gardeła 2013a, 109-22; Gardeła 2013b, 108-44), which is likely the case. However, herein we consider this evidence in the framework of judicial violence.

As might be expected from our analysis of the written evidence, direct evidence for criminal deviance is comparatively rare in Scandinavian archaeology. Gardeła highlights Grave F from Kumle Høje in Denmark, which contains the remains of two decapitated individuals, from whom only one skull has been found (Gardeła 2013a, 112; Gardeła 2013b, 113). The bodies were buried one atop the other, separated by a layer of soil (Gardeła 2013a, 112; Gardeła 2013b, 113). The lower individual was interred supine, the upper prone (Gardeła 2013a, 112; Gardeła 2013b, 113). Both had their feet bound, while one had a missing arm (Gardeła 2013a, 112; Gardeła 2013b, 113). It seems plausible, with Gardeła and Thäte, to call this the grave of two convicts.

A grave from Kalmargården (Denmark) may also contain the remains of at least one executed individual. Two mature decapitated males lie buried in a ditch (Gardeła 2013b, 114). Carbon 14 analysis could be interpreted as indicating that the two men were buried roughly twenty-five years apart, dated to 1015 and 1040 respectively, which others have suggested

44 For an introduction to deviant burial in Scandinavia, see Gardeła (2013a; 2013b), Price (2007), Riisøy (2015), and Thäte (2007).

45 Price (2007) and Svanberg (2003) have both commented extensively on this issue of funerary diversity in Scandinavia. 
indicates that the first burial was likely marked (Gardeła 2013b, 114). However, given the range of considerations that always applies to Carbon 14 dating, it is difficult to be certain that these were not contemporaneous burials. The man apparently buried first, the skeleton to the west, was laid in a supine position with his decapitated head placed between his legs (Gardeła 2013b, 114). The eastern skeleton was laid partially on one side, exhibiting slight flexion in the legs, arms crossed at the chest, and his decapitated skull placed between his legs (Gardeła 2013b, 114). While the western skeleton was oriented with the upper body to the north and the eastern skeleton to the northeast, this orientation is not necessarily significant, given the great variation of grave orientation in southeast Scandinavia at this time (Svanberg 2003, 25-130). What is significant is the pathology of the eastern skeleton. Gardeła remarks that the cut from the decapitation actually goes through the cranial base and the face (Gardeła 2013b, 114). We suggest that the man may have been kneeling with his chin to his chest at the time of decapitation, which points to execution, whether judicial or otherwise. This possibility is strengthened by his apparently careless deposition in a ditch. Of course, the western individual may also have been executed, even though he appears to have been laid out more carefully.

While these two graves are probably the best candidates for executed individuals, a number of further graves are suggestive of execution and demonstrative of mutilation. Grave 3 from Fjälkinge (Sweden) is a double grave, containing two superimposed individuals (Gardeła 2013b, 115). Not only is the upper skeleton decapitated but it also seems that the 'lower bones and feet [were] cut off' (Gardeła 2013b, 115). Their loss cannot be attributed to taphonomic disturbances (Svanberg 2003, 301). A burial from Gerdrup (Denmark) has been interpreted by David Wilson and others as possibly the grave of a convicted murderer - whose twisted cervical vertebrae suggest he died by hanging - and his victim (Wilson 2008, 34; Dutton 2016, 200-01); though Gardeła sees it as more likely to be the grave of a woman associated with magic and her slave (Gardeła 2013a, 117-18). Furthermore, Gardeła notes a number of graves that demonstrate a Scandinavian tradition of weighting or stoning bodies; differentiating one from the other is difficult as stones appear to have been laid on the bodies of the deceased, rather than thrown violently (Gardeła 2013a, 117-20; 2017, 180-95).

How do Gardela's inferences sit with the textual sources explored above? The first observation that comes from the Scandinavian archaeology is that execution and judicial violence were not nearly as visible nor as widespread as they were in England at the same time. This holds up very well with what we can synthesize from the textual sources. Given that many of the texts suggest that outlawry was a more common punishment than maiming or execution (Larson 1935, 17), we would not expect to find many individuals exhibiting signs of judicial violence in the archaeology. Furthermore, what archaeological evidence we have for judicial violence in Scandinavia fails to support the idea that the incredible executions depicted in the mythical literary texts had any known 'real world' counterparts (Larrington 1996, Dronke 1969). The two forms of execution that do show up in the archaeology are precisely those the textual evidence would lead us to expect: decapitations, with a few possible hangings (Gardeła 2013a, Gardeła 2013b, Peel 2015, Larson 1935). It is also worth noting that we have evidence for the removal of both feet and arms, the two most common mutilations mentioned in the legal texts (Gardeła 2013a, Gardeła 2013b, Peel 2015, Larson 1935). Intriguingly, there is little evidence in the Scandinavian deviant burial corpus for the display of executed bodies at this time. This is 
particularly noteworthy given the provision in Gulatingsloven to the effect that leaving a body unburied is highly dishonourable (Larson 1935, 160). ${ }^{46}$

A second observation can be made by noting that graves that exhibit evidence of execution and maiming are often found in normative cemeteries among normative burials, even in the graveyards of important centres and proto-towns like Hedeby and Birka (Gardeła 2013a 10910). ${ }^{47}$ Criminal deviants may not have been so ostracized by society that their remains warranted a separate place of disposal, as seems to have been the case in England (Gardeła 2013a, 109-10). Unfortunately, the texts are silent in this regard, but comment can still be made. While an outlaw lives, at least in theory, beyond the fringes of a normative society, ${ }^{48}$ making them unlikely additions to communal cemeteries, what of executed criminals? Bearing in mind cemeteries like those at Hedeby (Eisenschmidt 2011) and Birka (Gräslund 1980), or even smaller ones like at Fjälkinge (Gardeła 2013b, 115; Svanberg 2003, 301), there appears to be a strong tradition in Viking-Age Scandinavia of using cemeteries for remarkably long periods of time. These cemeteries exhibit immense variation across their constituents, displaying everything from apotropaic practices, through pre-Christian ritual activity, cremation, and Christian burial, to several possible examples of judicially-executed or maimed individuals (Gardeła 2013a, Gardeła 2013b, Svanberg 2003, 17-149). It may be most productive to consider these sorts of cemeteries simply as specialized spaces to dispose of the dead, regardless of creed or deed - complex places that could accommodate Christian and pre-Christian, law-abiding and criminal deviant alike. This interpretation seems to be corroborated by the evidence that Svanberg presents (Svanberg 2003, 17-149), and, given the ad hoc basis on which judicial violence seems to have been conducted by Viking-Age Scandinavians (Larson 1935, 129, 165, 263, 398), it would make sense to simply dispose of the body wherever would be most convenient - in this case, likely the local cemetery.

Comparing the English and Scandinavian contexts for judicial violence, it is clear that we are dealing with two very distinct frameworks with their own features and punitive attitudes. As demonstrated, the top-down English system of judicial violence is remarkably regimented, making its Scandinavian counterpart seem loosely defined by comparison. On the other hand,

46 However, consider the points raised by Dutton $(2016,133,135,142)$ regarding the display elements in ritual hanging and one case of penal hanging described in Östgötalagen stipulating the display of hanged slaves who had killed freemen. Despite these points, evidence of weathering and display in Scandinavian burials is slim indeed. For a longer discussion of western Norwegian deviant burials, see Riisøy (2015).

47 For an intriguing discussion of archaeological evidence for criminal activity in these prototowns, see Kalmring (2010).

48 The Íslendingasögur do contain details suggesting it may have been possible to remain in the community, especially sheltered by friends and relations, for example Gisla saga Súrssonar (Björn Pórólfsson and Guðni Jónsson 1943) and Grettis saga Ásmundarsonar (Gúðni Jónsson 1936). However, even in these cases, the legal agency and legitimacy of the titular characters are almost completely stripped away and, while they can remain in the proximity of the normative society, they are hardly empowered participants in it. Furthermore, Grettis saga Ásmundarsonar for example, contains intriguing reference to outlaws in Norway being buried below the highwater mark, again suggesting that outlaws were not conceived of as being counted among the normative population in life or in death. 
loose definition does not preclude sophistication. The Scandinavian system, with its concern for local social stability, suggests a more bottom-up approach. For example, if laws are enforced on a local level by semi-official members of the community (Larson 1935), the prevalence of outlawry as a punishment for criminal deviance is quite logical. It is more efficient to rule that a criminal is no longer a free member of society than to set in train the multiple legal steps toward a formal execution, such as those noted in Gulatingsloven (Larson 1935, 129). Though structurally distinct from the English system, the Scandinavian approach too creates a feedback loop in its bottom-up framework, keeping the population in order. With the freemen of the region meeting to decide the fate of the indicted individual, even if they did not actively participate in carrying out the sentence, the reality of the execution, maiming, or outlawing would be inescapable for them, and they would naturally carry news of it back to whichever corner of the district they came from. Thus, these two systems, though different in scope and scale, accomplish similar goals and reinforce specific legal norms in their respective societies.

\section{The Reign of Knútr}

Knútr inn ríki's English reign stands as a unique period in which to explore the potential for these two systems to interact in a set geopolitical space. As a successful monarch in both Denmark and England, Knútr would have been familiar with both systems described above and may have actively sought to integrate the two. To test this hypothesis, relevant legal, historical, and literary texts will be analyzed to consider the ways the judicial violence was being conceptualized during Knútr's reign; this will be followed by an examination of applicable archaeological evidence and, finally, we will synthesize the findings of each evidence set to demonstrate the high probability that Knútr and his officials may have been intentionally blending these two systems of punishment to novel effect.

Beginning with the laws and punishments decreed by Knútr, we see provisions for a diverse range of serious crimes which could lead to execution: violating the king's or the church's protection; thievery; treason against one's lord; repeat offences by slaves; failing to make a wergild payment; fighting in the king's court; breaching the peace; harbouring outlaws or the excommunicated; and desertion (Reynolds 2009, 259-61). ${ }^{49}$ The provisions for maiming were also revised under Knútr. Minters of false money, reeves who granted permission to do so, swearers of false oaths, and those who unlawfully wounded another all stood to lose a hand (or both in some cases). False accusers were to lose their tongues; slaves found guilty for a first offence were to be branded; and, in an innovation, an adulteress was to have her ears and nose removed (Reynolds 2009, 259-61). Outlawry was still prescribed for wizards, sorcerers, and prostitutes. Given an early provision that reeves should pronounce just sentences in keeping with the wishes of the local bishop and 'inflict such mitigated penalties as the bishop may approve and the man himself may be able to bear', it is likely that outlawry may also have been prescribed in other cases (see Reynolds 2009, 259-61).

49 Of course, Knútr did not promulgate all his laws at once; rather, the progression of his legal promulgations is historically significant and no doubt was instrumental to his success despite being an incoming foreign monarch. For a full discussion of this progression and its importance see Wormald (1999, 346-66). 
Many of these provisions perpetuated the English tradition of legally protecting the powerstructures of king, church, and state. In fact, Thompson notes an increased concern in the redemptive qualities of the church in Knútr's laws (Thompson 2004, 183-84). They also exhibit a conscious harkening back to the legal 'golden age' of Edgar and an attempt to affirm the legal interests of the English kings since Alfred (Wormald 1999, 131-33, 355), whether Knútr's own idea, or a result of the influence of Archbishop Wulfstan II. While Knútr's laws are clearly compiled in a strategic bid to establish him as patron and guardian of an English legal legacy (Wormald 1999, 349-52), there are hints Scandinavian legal attitudes operating in the margins. Wormald comments that the laws of Edgar, those most inspirational to Knútr's own, were already setting a legal precedent for Anglo-Scandinavian accommodation in England (1999, 34952), but Knútr's laws seem to push this accommodation one step further - toward a sort of integration of systems.

A disparity does exist between the character and extent of judicial violence prescribed in the Scandinavian provisions explored above and that seen in Knútr's English laws. ${ }^{50}$ However, there are several aspects to Knútr's provisions that demonstrate an interest in a more bottom-up approach to the administration of justice and dispensation of judicial violence. This is not as overt as it is in the Scandinavian laws but compared to the highly top-down legislation of Æðelred II the differences are clear. Not only is Knútr quick to ensure, in his very first proclamation, that justice should be dispensed fairly by his reeves, he also relegates judicial power back to the bishops (Reynolds 2009, 259). The church was also given the ability to grant legal protection to those who would seek it, a power shared only with Knútr himself. There is even room for local discretion in his legal provisions regarding the extent and character of judicial violence to be prescribed, as we learn that in certain cases 'he [the convicted] shall have his eyes put out and his nose and his ears and upper lip cut off or his scalp removed, whichever of these penalties is desired or determined upon by those with whom rests the decision of the case' (Reynolds 2009, 260).

Several of his provisions also exhibit a more Scandinavian flavor in their heightened interest in peace and stability on a local level. For example, the sudden increased concern with false oaths, adultery, and false accusations leading to injuries of honour are paralleled in the Scandinavian laws examined above (Larson 1935, 56, 59, 122-23, 132, 216-17, 244, 247-48, 251, 272, 366-67; Peel 2015, 209-10). The use of judicial violence in each of these provisions, both in the Scandinavian laws and in Knútr's English implementations is notable. Significantly, these very provisions in Knútr's laws eluded Patrick Wormald in his effort to trace precedents in pre-existing insular or continental legislation (1999, 356-60), making it likely that Knútr brought them with him over the North Sea. Given the lack of traceable parallels in insular and continental sources and the intriguing similarities in the Swedish and Norwegian analogues, these provisions may indeed be linked, especially in light of Knútr's mobility during his reign and the diversity of his following.

50 Recalling that the laws explored above are Norwegian and Gutnish in origin, we should not expect them perfectly mirror the judicial attitudes permeating Knútr's laws in either England, nor the contemporary Danish laws, which have been only sparsely preserved (Thurston 2001, 89-90). The better preserved analogues can, however, give us an idea of legal norms and protections in Denmark. Furthermore, transmitting the spirit of Scandinavian legal provisions to Knútr's English sphere of influence likely would have resulted in a change in the letter of those laws. 
With that in mind, the next step is to drill down in more detail, focusing on individual ASC entries relating to Knútr's activity. For example, the entry for 1016, gives a vignette of Uhtred's submission to Knútr. This entry seems strange because, even though Uhtred submits and gives hostages, he is slain at the advice of Knútr's followers (Swanton 1996, 146-53). Perhaps Uhtred's submission was 'out of necessity', 51 as Bolton suggests $(2009,118)$, and he was slain because he was seen as untrustworthy. Whatever the case, Knútr had not yet established his judicial authority in England by 1016 (Reynolds 2009, 259), meaning that Uhtred was probably not a judicial casualty but an unfortunate prisoner-of-war.

The story is altogether different in 1017, when the ASC records Knútr's attempts some political spring-cleaning in his court. The annalist records the slaying of his former allies, Ealdorman Eadric, Norðman, Æðelword, and Brihtric, as well as the banishment and subsequent execution of Ædwig and Eadwig, 'the ceorls' king' (Swanton 1996, 154-55; Earl and Plummer $1965,155)$. These events, unlike the slaying of Uhtred, seem to have judicial aspects to them. Not only are Eadric, Norðman, Æðelword, and Brihtric conducted to London for their slayings but also their juxtaposition in the text is noteworthy. Bolton highlights the $A S C$ 's tendency to paint Eadric as treacherous and suggests, extrapolating from the $A S C$ testimony, that those listed alongside him had joined Eadric in orchestrating a failed treason (Bolton 2009, 37; 44-5; 69). Knútr's apparent role in the exile of \#dwig and Eadwig and his subsequent order that they be slain is, if we take up Bolton's suggestion, Knútr's solution to an attempted coup (Bolton 2009, 46). Although, according to the $A S C$ (Wormald 1999, 346), Knútr did not proclaim legal authority in England until 1018, we argue tentatively that the episode is best considered as an expression of judicial violence, due to its concern with political and legal details.

After the 1018 legal proclamation, the ASC is almost silent on Knútr's use of judicial violence. In 1021 we learn that he personally outlawed Porkell and in 1022 that abbot Leofwine was 'unjustly' exiled (Swanton 1996, 154-57). Yet the $A S C$ goes on to note that Leofwine was cleared the very same year he was banished and Knútr and Porkell reconciled only a year afterward (Swanton 1996, 154-57). The use of utlagian in Porkell's case is suggestive of judicial practice, as is the concern with justice in Leofwine's case. Furthermore, that both men were cleared of their charges and allowed to return brings to mind provisions for lesser outlawry, like those in the early Norwegian laws discussed above (Larson 1935, 17).

These examples give us an insight into Knútr's use of judicial violence in his reign. Most significantly, in contrast to his apparently liberal use of military violence Knútr's use of judicial violence is quite restricted. After his 1018 proclamation, the only signs of judicial violence in $A S C$ entries are the three possible cases of judicial outlawry. In fact, even before the proclamation, Knútr's possible uses of judicial violence seem to have been reserved for cases of political treachery (Bolton 2009, 37; 44-46; 69). This picture aligns with the conciliatory nature of his laws and resonates particularly well with many of the provisions in the Norwegian laws.

Skaldic poetry from Knútr's reign clarify the picture further, with the poems of Sigvatr Pórðarson being especially relevant to our current discussion (Whitelock 1955, 311), ${ }^{52}$ exhibiting the same conciliatory spirit that we have already noted. For example, Sigvatr in one of his lausavisur states that instead of seeking retaliation Knútr received Scottish nobles from Fife and

51 Earl and Plummer 1965, 149, '7 beah ða for nyde.'

52 See Townend 2001 and Jesch 2000 for discussions of other Knútr poems. 
reconciled with them, allowing them to purchase peace in exchange for their lives (Fulk 2012, 714).

Hafa allframir jofrar

út sín hofuð Knúti

forð ór Fífi norðan

- friðkaup vas pat - miðju.

Seldi Ôleifr aldri

(opt vá sigr) inn digri

haus í heimi (pvísa

hann) engum svá manni.

The most outstanding lords have presented their heads to Knútr from the north out of mid Fife; it was the price of peace. Óláfr the Stout never surrendered his skull thus to anyone in the world; he has often won victory for that reason (Fulk 2012, 714).

Much like Knútr's reconciliations with Leofwine and Porkell, the settlement recounted by Sigvatr has the familiar ring of the skógarkaup provisions discussed above (Larson 1935, 17), but perhaps even more interesting is the second stanza in his Vestrfararvísur.

Útan varðk, áðr Jóta

andspilli fekk'k stillis,

— melld sák hús fyr hauldi -

húsdyrr fyrir spyrjask.

En eyrendi óru

ôttungr í sal knátti

Gorms - berk opt á armi

járnstúkur - vel lúka.

I had to make enquiries from outside the main door before I got an audience with $\{$ the ruler of the Jótar\} [DANISH KING = Knútr]; I saw a locked building in front of the man [me]. But $\{$ the descendant of Gormr $\}$ [DANISH KING = Knútr] was able to conclude our [my] errand well in the hall; I often wear iron sleeves on my arm (Jesch 2012, 618).

Demonstrating typical skaldic ambiguity, the language here is interesting from a judicial perspective. Eyrendi, referring to Sigvatr's purpose for meeting Knútr, as well as the word lúka for its conclusion can both carry legal connotations. This paired with Sigvatr's apparent care waiting for an audience could suggest that that Sigvatr himself came to Knútr's court with a case against him (Whitelock 1955, 311-12). ${ }^{53}$

Of course, Knútr's conciliatory nature cannot be ascribed to a more Scandinavian or English judicial temperament, nor can the purchasing of peace. While his interest in seeking settlements could be borne out of his native bottom-up punitive system, it is equally possible that it arose

53 The wider context of the poem mentions that Sigvatr entered Knútr's following and can be read as a justification of his divided loyalties over his career (Jesch 2012, 615). 
from his involvement with Archbishop Wulfstan II. ${ }^{54}$ In reality, it was most likely due to a combination of these factors. As noted above, Wormald points out that the laws of Edgar were already setting legal precedent for Anglo-Scandinavian accommodation in England (Wormald 1999, 352-55) but, given the evidence here, Knútr's laws seem to encourage a hybridization of systems.

Recent archaeological studies point to a wider culture of Anglo-Scandinavian hybridization around this time. However, the burial evidence explored above is too broadly dated to be applied to a precise historical case study like Knútr's reign. ${ }^{55}$ Instead, material culture allows us to focus on cultural interaction and idea-transfer, considering Knútr as an agent of social and legal changes in his day. Given his kingship over both Denmark and England it is likely that he was influential in the hybridization of ideas between Scandinavia and England including, perhaps, the frameworks for judicial violence.

Archaeological evidence for cultural interaction and idea-transfer to corroborate this hypothesis abounds. Analysis of material culture from across the Anglo-Scandinavian world repeatedly indicates that artistic, technological, and cultural hybridity were characteristics of this time (Ashby 2011, 313-6; Kershaw 2009, Kershaw 2013, Stocker 2000; Thomas 2000, 239-52). Owen and Driscoll (2011, 341-43), examining stone sculptures on the Firth of Clyde, highlight a number of hogback carvings associated with members of a Norse elite in the tenth and eleventh centuries, alongside evidence for what appears to be a high-status thing-site. This hints at the possibility of political and, given the possible thing-site, even legal integration (Owen and Driscoll 2011, 343). The chronological span of this evidence overlaps Knútr's reign and potentially significant is Sigvatr Pórðarson's verse on Knútr's interaction with Scottish nobles above.

Some of this evidence predates Knútr's reign and points to an earlier framework for AngloScandinavian accommodation of artistic and stylistic ideas, but also social, judicial, and even theological conceptual exchange and hybridization (Thomas 2000, Kershaw 2010, Stocker 2000, Owen and Driscoll 2011). ${ }^{56}$ Knútr seems to have actively continued this legacy, using his remarkable mobility during his reign to facilitate ideological blending and accommodation (Bolton 2005). The diversity of his following only further suggests an intentionally pragmatic approach to governance. Evidence of this can be seen in Bolton's observation that Knútr was successful in installing new Scandinavian royal offices into the existing machinery of English governance (Bolton 2009, 63). In light of this record of hybridization and Knútr's bureaucratic innovations, the implementation of new judicially violent punishments, yet untraceable to previous English legislation and with strong Scandinavian parallels, certainly points to a degree of legal accommodation occurring with Knútr at the helm.

54 For discussions of this relationship, see Thompson (2004, 183-4) and Wormald (1999, 352-5).

${ }^{55}$ Even very highly-resolved evidence, like that of Grave 9 at Walkington Wold in East Yorkshire - the dating of which significantly overlaps Knútr's reign (Reynolds 2009, 150-51) is rather unhelpful, given its full date range of $900-1040$.

56 Richards provides an overview of these changes in Anglo-Scandinavian England (Richards 2010, 226-27), while Else Roesdahl illustrates that these exchanges were also happening further afield as the North Sea became a cultural melting pot of sorts in the tenth and eleventh centuries (Roesdahl 2011, 368-69). 


\section{Conclusions}

In investigating the systems and structures of judicial violence and punishment above, several key findings come to the fore. First, we have demonstrated distinctive English and Scandinavian approaches to the use and conceptualization of judicial violence. This has been made visible through the integration of diverse sources and evidence sets. The prevailing picture revealed by this analysis points to a top-down approach in England, while the Scandinavian evidence suggests a more bottom-up approach. Second, we have been able to point to evidence of these systems interacting and perhaps hybridizing, both in textual sources and in archaeological evidence, during Knútr the Great's English reign. The politically-motivated acculturation of these systemic approaches to punishment yields some insight into the context of contemporaneous law-making and revision. Legal and punitive systems are a complex tapestry of conservatism and innovation, local tradition, and foreign import, and have to be read within this context. Third, our investigation has highlighted the tricky interlocution of violent punishment, political motivation, and the maintenance or protection of social norms, as well as suggesting some ways of engaging with this unwieldy cluster of concepts.

Returning to Alison Klevnäs's recent comments on institutionalized violence and necropolitics, as all societies face challenges to social equilibrium - be it legal, political, or otherwise - the responses to those threats can be particularly telling. The observations in this paper have pointed to a characteristic pragmatism in the ways in which punitive systems and judicial violence were manipulated and revised in the Viking Age. This pragmatism demonstrates an interest in legal flexibility in order to respond to the increased diversity, cultural contact, changing religious contexts, and developments in governance that stand out as key elements of the Viking Age.

\section{Works Cited}

\section{Primary Sources}

Björn Pórólfsson and Guðni Jónsson, ed. 1943. Gísla saga Súrssonar, in Vestfirðinga Sögur, Íslenzk Fornrit 6, Reykjavík: Íslenzk Fornrit

Bradley, Sidney A. J., ed. 1995. Anglo-Saxon Poetry, London: Everyman

Clark Hall, John R. 1960. A Concise Anglo-Saxon Dictionary, Toronto: University of Toronto Press

Dronke, Ursula, ed. 1969. The Poetic Edda: Volume I, Oxford: Oxford University Press

Earl, John and Charles C. Plummer, ed. 1965. Two Saxon Chronicles Parallel, Oxford: Oxford University Press

Finlay, Alison and Anthony Faulkes, ed. 2011. Heimskringla: Volume I, Exeter: Viking Society for Northern Research 
Fulk, Robert D., Robert E. Bjork, and John D. Niles, ed. 2008. Klaeber's Beowulf, Toronto: University of Toronto Press

Fulk, Robert D., ed. 2012. 'Sigvatr Pórðarson, Lausavísur 12' in Skaldic Poetry of the Scandinavian Middle Ages 1: Poetry from the Kings' Sagas 1: From Mythical Times to c. 1035, ed. Diana Whaley, Turnhout: Brepols, 714

Gade, Kari Ellen, ed. 2012. 'Hildr Hrólfsdóttir nefju, Lausavísa 1' in Skaldic Poetry of the Scandinavian Middle Ages 1: Poetry from the Kings' Sagas 1: From Mythical Times to c. 1035, ed. Diana Whaley, Turnhout: Brepols, 139

Gúđni Jónsson, ed. 1936. Grettis Saga Ásmundarsonar, Íslenzk Fornrit 7, Reykjavík: Íslenzk Fornrit.

Jesch, Judith, ed. 2012. 'Sigvatr Pórðarson, Vestrfararvísur' in Skaldic Poetry of the Scandinavian Middle Ages 1: Poetry from the Kings' Sagas 1: From Mythical Times to c. 1035, ed. Diana Whaley, Turnhout: Brepols, 615-626.

Krapp, George. P. and Elliot van Kirk Dobbie, ed. 1936. The Exeter Book, New York: Columbia University Press

Larrington, Carolyne, ed. 2008. The Poetic Edda, Oxford: Oxford University Press

Larson, Laurence. M., ed. 1935. The Earliest Norwegian Laws. New York: Columbia University Press

Marold, Edith, ed. 2012. 'Pjóðólfr ór Hvini, Ynglingatal' in Skaldic Poetry of the Scandinavian Middle Ages 1: Poetry from the Kings' Sagas 1: From Mythical Times to c. 1035, ed. Diana Whaley, Turnhout: Brepols, 3-58

Peel, Christine, ed. 2015. Guta lag and Guta saga, Exeter: London: Routledge

Poole, Russell, ed. 2012. 'Eyvindr skáldaspillir Finnsson, Háleygjatal' in Skaldic Poetry of the Scandinavian Middle Ages 1: Poetry from the Kings' Sagas 1: From Mythical Times to c. 1035, ed. Diana Whaley, Turnhout: Brepols, 195-212

Poole, Russell, ed. 2012. 'Torf-Einarr Rognnaldsson, Lausavísur' in Skaldic Poetry of the Scandinavian Middle Ages 1: Poetry from the Kings' Sagas 1: From Mythical Times to c. 1035, ed. Diana Whaley, Turnhout: Brepols, 129-137

Swanton, Michael J. ed. 1996. The Anglo-Saxon Chronicle, London: J. M. Dent

Whitelock, Dorothy, ed. 1995. English Historical Documents: c. 500-1042, Taylor \& Francis 


\section{Secondary Sources}

Abrams, Lesley. 2000. 'Conversion and Assimilation', in Cultures in Contact: Scandinavian Settlement in England in the Ninth and Tenth Centuries, ed. Dawn M. Hadley and Julian D. Richards, Studies in the Early Middle Ages 2, Turnhout: Brepols, 135-153

Ashby, Steven P. 2011. 'A Study in Regionality: Hair Combs and Bone/Antler Craft in NorthEast England c. AD 800-1100', in Early Medieval Northumbria, ed. David Petts and Sam Turner, Studies in the Early Middle Ages 24, Turnhout: Brepols, 303-316

Aspöck, Edeltraud. 2010. 'What Actually is a "Deviant Burial"? Comparing German-Language and Anglophone Research on 'Deviant Burials', in Deviant Burial in the Archaeological Record, ed. Eileen M. Murphy, Studies in Funerary Archaeology 2, Oxford: Oxbow Books, 1734

Aspöck, Edeltraud. 2011. 'Past "Disturbances" of Graves as a Source: Taphonomy and Interpretation of Reopened Early Medieval Inhumation Graves at Brunn am Gebirge (Austria) and Winnall II (England)', Oxfrod Journal of Archaeology 30.3, 299-324

Aspöck, Edeltraud. 2015. 'Funerary and Post-Depositional Body Treatments at the Middle Anglo-Saxon Cemetery Winnall II. Norm, Variety and Forms of Deviance', in Death Embodied: Archaeological Approaches to the Treatment of the Corpse, ed. Zoë. L. Devlin and Emma. J. Graham, Studies in Funerary Archaeology 9, Oxford: Oxbow, 86-108

Bagge, Sverre. 2008. Order, Disorder and Disordered Order: Interpretations of the World and Society from the Pagan to the Christian Period in Scandinavia, Cambridge: Department of Anglo-Saxon, Norse, and Celtic

Bagge, Sverre. 2010. From Viking Stronghold to Christian Kingdom: State Formation in Norway, c. 900-1350, Copenhagen: Museum Tusculanum Press

Baier, Matthias. 2013. Social and Legal Norms: Towards a Socio-legal Understanding of Normativity, Surrey: Ashgate Publishing Ltd.

Bolton, Timothy. 2005. 'An Historical Perspective on the Recent Archaeological Discoveries at Viborg Sønders $\varnothing$ ', in Viborg Sønders $\varnothing 1018$-1030, ed. Mette Iversen and others., Jysk Arkæologisk Selskab Skrifter 52, Århus: Jysk Arkæologisk Selskab, 499-502

Bolton, Timothy. 2009. The Empire of Cnut the Great. Leiden: Brill

Brink, Stefan. 2007. 'Law and Society: Polities and Legal Customs in Viking Scandinavia', in The Viking World, ed. Stefan Brink and Neil Price, London: Routledge, 23-31

Brink, Stefan. 2013. 'The Creation of a Scandinavian Provincial Law', Historical Research 86. $233,432-442$ 
Brink, Stefan. 2014. 'The Hälsinge Law Between South and West, King and Church, and Local Customs', in New Approaches to Early Law in Scandinavia, ed. Stefan Brink and Lisa Collinson, Turnhout: Brepols, 37-56

Brink, Stefan. 2015. 'Early Law in the North' in Quaestio Insularis 16. 1-15

Buckberry, Jo L. 2010. 'Off With Their Heads: the Anglo-Saxon Execution Cemetery at Walkington Wold, East Yorkshire', in Deviant Burial in the Archaeological Record, ed. Eileen M. Murphy, Studies in Funerary Archaeology 2, Oxford: Oxbow Books, 148-168

Buckberry, Jo L. and Dawn M. Hadley. 2007. 'An Anglo-Saxon Execution Cemetery at Walkington Wold, Yorkshire', Oxford Journal of Archaeology 26.3, 309-329

Chenery, Carolyne A., Jane A. Evans, David Score, Angela Boyle, and Simon R. Chenery. 2014. 'A Boat Load of Vikings?', Viking Settlers in the North Atlantic: An Isotopic Approach, Journal of the North Atlantic 7, 43-5

Cherryson, Anita K. 2010. 'Normal, Deviant and Atypical: Burial Variation in Late Saxon Wessex, c. AD 700-1100', in Deviant Burial in the Archaeological Record, ed. Eileen M. Murphy, Studies in Funerary Archaeology 2, Oxford: Oxbow Books, 115-130

Clark, David. 2012. Gender, Violence, and the Past in Edda and Saga, Oxford: Oxford University Press

Dutton, Douglas. 2016. ‘An Encapsulation of Óðinn’ (unpublished doctoral thesis. University of Aberdeen)

Eisenschmidt, Silke. 2011. 'The Viking Age Graves from Hedeby', in Viking Settlements and Viking Society: Papers From the Proceedings of the Sixteenth Viking Congress, ed. Svavar Sigmundsson, Reykjavík: Hið íslenzka fornleifafélag and University of Iceland Press, 83-102

Ekholst, Christine. 2014. A Punishment for Each Criminal: Gender and Crime in Swedish Medieval Law, The Northern World 67, Leiden: Brill

Gardeła, Leszek. 2013a. 'The Dangerous Dead? Rethinking Viking-Age Deviant Burials', in Conversions: Looking for Ideological Change in the Early Middle Ages, ed. Leszek Słupecki and Rudolf Simek, Vienna: Verlag Fassbaender, 99-136

Gardeła, Leszek. 2013b. 'The Headless Norsemen: Decapitation in Viking Age Scandinavia', in The Head Motif in Past Societies in a Comparative Perspective, ed. Leszek Gardeła and Kamil Kajkowski, Bytów: Muzeum Zacodniokaszubskie w Bytowie, 88-155

Gardeła, Leszek. 2017. Bad Death in the Early Middle Ages: Atypical Burials from Poland in a Comparative Perspective, Collectio Archaeologica Ressoviensis Tomus 36, Rzeszów: Instytut Archeologii UR 
Gräslund, Anne-Sophie. 1980. Birka. IV, The burial customs: a study of the graves on Björkö, Stockholm: Almquist \& Wiksell

Guðmundur Ólafsson, Kevin P. Smith, and Thomas McGovern. 2010. 'Surtshellir: a fortified outlaw cave in West Iceland' in The Viking Age: Ireland and the West: Proceedings of the Fifteenth Viking Congress, Cork, 2005 ed. John G. Sheehan and Donnchadh Ó Corráin, Dublin: Four Courts Press, 283-297

Hadley, Dawn. M. 2011. 'Protecting the Dead in Viking Age England', in Viking Settlements and Viking Society: Papers From the Proceedings of the Sixteenth Viking Congress, ed. Svavar Sigmundsson, Reykjavík: Hið íslenzka fornleifafélag and University of Iceland Press, 201-208

Hall, Steve. 2012. Theorizing Crime and Deviance: a New Perspective, London: SAGE

Hastrup, Kirsten. 1985. Culture and History in Medieval Iceland, Oxford: Oxford University Press

Helle, Knut. 2001. Gulatinget og Gulatingslova, Leikanger: Skald

van Houts, Elisabeth. 2010. 'The Vocabulary of Exile and Outlawry in the North Sea Area around the First Millennium', in Exile in the Middle Ages, ed. Laura Napran and Elisabeth van Houts, Turnhout: Brepols, 13-28

Jesch, Judith. 2000. 'Knútr in Poetry and History', in International Scandinavian and Medieval Studies in Memory of Gerd Wolfgang Weber, ed. Michael Dallapiazza and others., Trieste:

Edizioni Parnaso, 243-256

Jorgensen, Alice. 2010. 'Introduction: Reading the Anglo-Saxon Chronicle', in Reading the Anglo-Saxon Chronicle, ed. Alice Jorgensen, Turnhout: Brepols, 1-28

Jón Viðar Sigurðsson. 2017 Viking friendship : the social bond in Iceland and Norway, c. 9001300, Ithica: Cornell University Press

Kalmring, Sven. 2010 'Of thieves, counterfeiters and homicides. Crime in Hedeby and Birka', in Fornvännen 105, 281-290

Kershaw, Jane F. 2009. 'Culture and Gender in the Danelaw: Scandinavian and AngloScandinavian Brooches', in Viking and Medieval Scandinavia 5, 295-325

Kershaw, Jane F. 2013. Viking Identities. Oxford: Oxford University Press

Klevnäs, Alison. 2016a. 'Deaths Matter', in Current Swedish Archaeology 24, 49-56

Klevnäs, Alison. 2016b. 'Overkill: Reopening Graves to Maim the Dead in Anglo-Saxon England', in The Head Motif in Past Societies in a Comparative Perspective, ed. Leszek Gardeła and Kamil Kajkowski, Bytów: Muzeum Zacodniokaszubskie w Bytowie, 177-213 
Lambert, Tom. 2012. 'Anglo-Saxon Deviant Burial Customs, by Andrew Reynolds', in The English Historical Review CXXVII, Oxford: Oxford University Press, 678-80

Lambert, Tom. 2017. Law and Order in Anglo-Saxon England, Oxford: Oxford University Press

Lapidge, Michael, John Blair, Simon Keynes, and Donald Skragg. 2014. The Wiley Blackwell Encyclopedia of Anglo-Saxon England, second edition, Chichester: John Wiley \& Sons Ltd.

Lindow, John. 2001. Norse Mythology: A Guide to the Gods, Heroes, Rituals, and Beliefs, Oxford: Oxford University Press

Moreland, John. 2003. Archaeology and Text, London: Duckworth

Niles, John D. 2007. Old English Heroic Poems and the Social Life of Texts, Studies in the Early Middle Ages 20, Turnhout: Brepols

Owen, Olwyn A. and Stephen T. Driscoll. 2011. 'Norse Influence at Govan on the Firth of Clyde, Scotland', in Viking Settlements and Viking Society: Papers From the Proceedings of the Sixteenth Viking Congress, ed. Svavar Sigmundsson, Reykjavík: Hið íslenzka fornleifafélag and University of Iceland Press, 333-346

Pons-Sanz, Sara M. 2010. 'Norse-Derived Vocabulary in the Anglo-Saxon Chronicle'. In Reading the Anglo-Saxon Chronicle, ed. Alice Jorgensen. Turnhout: Brepols, 275-304

Price, Neil. 2007. 'Dying and the Dead: Viking Age Mortuary Behaviour in Viking Scandinavia.' in The Viking World, ed. Stefan Brink and Neil Price, London: Routledge, 257-273

Reynolds, Andrew. 1999. Later Anglo-Saxon England. Stroud: Tempus

Reynolds, Andrew. 2009. Anglo-Saxon Deviant Burial Customs. Oxford: Oxford University Press

Richards, Julian D. 2005. The Vikings: A Very Short Introduction. New York: Oxford University Press

Richards, Julian D. 2010. Viking Age England. 2nd edition. Stroud: The History Press

Riisøy, Anne Irene. 2009. Sexuality, Law and Legal Practice and the Reformation in Norway, The Northern World 44, Leiden: Brill

Riisøy, Anne Irene. 2014. 'Outlawry: From Western Norway to England', in New Approaches to Early Scandinavian Law, ed. Stefan Brink and Lisa Collinson, Acta Scandinavica 3, Turnhout: Brepols, 101-129 
Riisøy, Anne Irene, 2015. 'Deviant Burials: Societal Exclusions of Dead Outlaws in Medieval Norway', in COLLeGIUM 18, 49-81

Roesdahl, Else. 2011. 'Scandinavia in the Melting-Pot, 950-1000', in Viking Settlements and Viking Society: Papers From the Proceedings of the Sixteenth Viking Congress, ed. Svavar Sigmundsson, Reykjavík: Hið íslenzka fornleifafélag and University of Iceland Press, 347-374

Ruiter, Keith. 2014. 'Visibility, Authority, and Execution in Heimskringla', in Illuminating the North: Proceedings from the Nordic Research Network conference 2013, ed. Agnes Broomé and others, London: Norvik Press, 119-32

Sanmark, Alexandra. 2009. 'Administrative Organisation and State Formation: A Case Study of Assembly Sites in Södermanland, Sweden’, Medieval Archaeology 53, 205-241

Sanmark, Alexandra and Sarah J. Semple. 2008. 'Places of Assembly: New Discoveries in Sweden and England', in Fornvännen 103, 245-259

Sayer, Duncan 2013. 'Christian Burial Practice in the Early Middle Ages: Rethinking the AngloSaxon Funerary Sphere', History Compass 1, 133-46

Stocker, David. 2000. 'Monuments and merchants: Irregularities in the distribution of stone sculpture in Lincolnshire and Yorkshire in the tenth century', in Cultures in Contact:

Scandinavian Settlement in England in the Ninth and Tenth Centuries, ed. Dawn M. Hadley and Julian D. Richards, Studies in the Early Middle Ages 2, Turnhout: Brepols, 179-212

Ström, Folke. 1942. On the Sacral Origin of the Germanic Death Penalties. Lund: Håkan Ohlssons Boktryckeri

Ström, Folke. 1974. Nið, ergi and Old Norse Moral Attitudes. London: Viking Society for Northern Research

Svanberg, Fredrik. 2003. Death Rituals in South-East Scandinavia AD 800-1000, Decolonizing the Viking Age 2, Stockholm: Almqvist \& Wiksell International

Tamm, Ditlev. 2011. 'How Nordic are the Old Nordic Laws?', in How Nordic are the Nordic Medieval Laws? Proceedings from the first Carlsberg Conference on Medieval Legal History Second Edition 2011, ed. Per Andersen, Ditlev Tamm, and Helle Vogt, Copenhagen: DJØF Publishing, 5-21

Thomas, Gabor. 2000. 'Anglo-Scandinavian metalwork from the Danelaw: Exploring social and cultural interaction', in Cultures in Contact: Scandinavian Settlement in England in the Ninth and Tenth Centuries, ed. Dawn M. Hadley and Julian D. Richards, Studies in the Early Middle Ages 2, Turnhout: Brepols, 237-255

Thompson, Victoria. 2004. Dying and Death in Later Anglo-Saxon England, Woodbridge: The Boydell Press 
Thurston, Tina. L. 2002. Landscapes of Power, Landscapes of Conflict: State Formation in the South Scandinavian Iron Age, Dordrecht: Springer

Thäte, Eva. S. 2007. Monuments and minds: Monument re-use in Scandinavia in the second half of the first millennium AD, Acta Archaeologica Lundensia Series in quarto 27 Lund: Wallin \& Dalholm

Townend, Matthew. 2001. 'Contextualizing the Knútsdrápur: Skaldic Praise-Poetry at the Court of Cnut', Anglo-Saxon England 30, 145-179

Walker, Jenny. 2011. 'The Recursive Structuring of Space: Socio-Political and Religious performance in the Hall', in Early Medieval Northumbria, ed. David Petts and Sam Turner, Studies in the Early Middle Ages 24, Turnhout: Brepols, 221-235

Whitelock, Dorothy. 1954. The Beginnings of English Society, London: Penguin

Wilson, David. 2008. The Vikings in the Isle of Man, Aarhus: Aarhus University Press

Wormald, Patrick. 1999. The Making of English Law: King Alfred to the Twelfth Century: Volume I, Oxford: Blackwell 